\title{
MEMBERDAYAKAN ANAK-ANAK MELALUI GELAR TIKAR (STUDI KASUS ANAK-ANAK PANTI ASUHAN DI KOTA DEPOK JAWA BARAT)
}

\author{
Agustinus Rustanta*, Devany Dwi Putri Halim, Bella Damaica Sabatini, Nuzlita Andarini \\ Program Studi Ilmu Komunikasi, Sekolah Tinggi Ilmu Komunikasi Dan Sekretaris Tarakanita, Jakarta, Indonesia \\ *Penulis korespondensi: rustanta15002@gmail.com
}

\begin{abstract}
Abstrak
Artikel ini merupakan artikel tentang pelaksanan pengabdian kepada masyarakat oleh civitas akademik STIKS Tarakanita. Para pengabdi adalah dosen dan mahasiswa program studi Ilmu Komunikasi yang tergerak untuk membina anak-anak yatim-piatu di Depok Jawa Barat. Tujuan layanan inia dalah untuk memberdayakan anak-anak yatim piatu. Metode yang digunakan dalam melaksanakan pendampingan kepa da a nak-anak ini adalah dengan mendampingi mereka dalam belajar; belajar Bahasa Inggris dan pendampingan mengerjakan Pekerjaan Rumah (PR) sekolah mereka. Kegia tan tersebut tidak hanya bermanfaat bagi a nakanak panti a suhan nemun juga berguna bagi para mahasiswa sebagai pendamping. Mahasiswa mendapat pengalaman mengelola anak-anak untuk memanfaatkan waktu dengan kegiatan yang positif, mahasiswa mendapatkan pembelajaran untuk bersabar dan kreatif sehingga kegiatan tersebut dapat berjalan dan menyenangkan sehingga a nak-anak termotivasi untuk memanfaatkan waktu luang mereka dengan hal-hal yang bermanfaat. Anak-anak panti asuhan juga mendapatkan pembimbingan yang rutin dila kukan oleh para mahasiswa.
\end{abstract}

Kata kunci: Layanan; Gelar Tikar; Yatim-Piatu; Pengabdian Kepada Masyarakat.

\begin{abstract}
It is about student's participation to Campus Social Responsibility of STIKS Tarakanita civitas Academica. The participants are a lecturer and students of communication study program and the subjects of this activity are are children in an orphanage house in Depok, $30 \mathrm{~km}$ from campus. The objective of the service is to empower the unlucky children. Method used is accompanying them to do something useful such as learning English and studying for their lessons. By doing so, they do not wander on the street and in malls nearby. By doing this kind of activity, there are two parties getting the advantages from this social service activity. Students are learning how to teach others. It is something usefulfor their lives and the students are also learning how to appreciate their teachers. On the other hand, the children of Gelar Tikar spend their time with something beneficial to their lives.
\end{abstract}

Keywords: Gelar Tikar; Social Service; Orphanage; Campus Social Responsibility.

\section{PENDAHULUAN}

Pada dasarnya perguruan tinggi wajib menyelenggarakan Tridharma Perguruan Tinggi. Yang dimaksud dengan Tridharma Perguruan Tinggi menunut UU No. 12 tahun 2012 adalah menyelenggarakan Pendidikan, Penelitian, dan Pengabdian kepada Ma syarakat. Dharma ketiga merupakan kegiatan civitas academika memajukan kesejahteraan masyarakat. Bentuk pengabdian kepada masyarakat oleh perguruan tinggi disesuaikan dengan keahlian yang dimiliki perguruan tinggi, budaya akademik yang dihidupi atau kondisi masyarakat yang menjadi sasaran kegiatan.

Pengabdian kepada Masyarakat tidak hanya dilakukan oleh dosen namun oleh civitas akademik yang di dalamnya termasuk mahasiswa. Mahasiswa dituntut tidak hanya menuntut ilmu di kampus namun juga dapat terlibat dalam penelitian bersama-sama dosen atau melakukan pengabdian kepada masyarakat.
Banyak cara mahasiswa belajar, antara lain dengan melakukan kegiatan pengabdian kepada masyarakat. Dalam konteks pengabdian kepada masyarakat, mahasiswa belajar tidak harus melalui bangku ku liah. Belajar dapat dilakukan secara langsung di masyarakat dengan cara terlibat langsung memecahkan permasalahan sosial yang terjadi sesuai dengan potensi dan kebutuhan di lapangan. Mahasiswa perlu melakukan terobosan baru yang bersifat memberdayakan (empowerment) sehingga mayarakat ditantang untuk memiliki kemampuan dan kemandirian.

Salah satu kegiatan yang dilakukan oleh mahasiswa tingkat akhir adalah kerja magang dan Kuliah Kerja Nyata (KKN) yang merupakan bentuk pengabdian kepada masyarakat yang bersifat wajib. Wajib karena kegiatan ini termasuk kegiatan intra kurikuler yang wajib ditempuh oleh mahasiswa dengan bobot 3-6 sks. 
KKN itu sendiri diperkenalkan pada tahun 1971 oleh Prof. Koesnadi Hardjasoemantri, SH yang kemudian ga ga san tersebut direstuioleh Presiden pada tahun 1972 sebagai kegiatan mahasiswa dan dimasukkan sebagai ba gian dari kurikulum. Sekarang istilah KKN menjadi Pos Pemberdayaan Masyarakat (Posdaya) (Rumambi et al, 2012) dan (Atmojo et al, 2017) yang diga gas oleh Prof, Haryono Suyono tahun 2006.

Mahasiswa dapat melaksanakan pengabdian kepada masyarakat dalam beberapa bentuk kegiatan sederhana selain KKN dan kerja magang. Salah satunya adalah dengan kerja bakti, bakti sosial, mengunjungi panti a suhan, mengumpulkan dana untuk disumbangkan ke panti asuhan atau pihak-pihak yang membutuhkan. Kegiatan tersebut dapat memberi manfaat untuk melatih empati para mahasiswa dan menjadi sarana untuk mengaplikasikan ilmu pengetahuan yang mereka peroleh di kampus (Setyawan, 2010). Tak ketinggalan oleh mahasiswa Sekolah Tinggi Tarakanita. Mereka ikut aktif melaksanakan kegia tan mendampingi a nakanak yang setiap hari berkeliaran di mal-mal sekitar mereka tinggal pa dajam sekolah.

Melihat fenomena tersebut, mahasiswa tergerak untuk mengarahkan anak-anak menuju hal-hal yang bermanfaat. Mahasiswa secara suka rela meluangkan waktunya untuk menjadi pendamping anak-anak dan berupaya untuk menghindarkan mereka dari penganuh negatif danjuga penculikan anak.

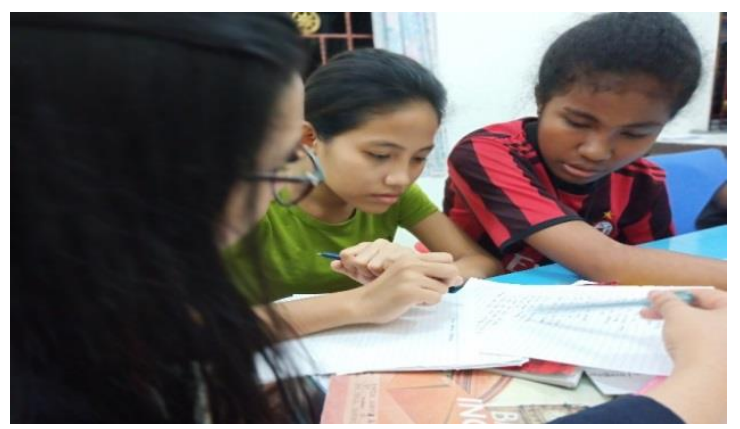

Gambar 1. Seorang mahasiswa sedang mendampingi a nak panti untuk belajar.

Gemar belajar Tarakanita atau yang biasa disebut dengan Gelar Tikar merupakan salah satu kegiatan mahasiswa ilmu komunikasi Sekolah Tinggi Tarakanita. Berawal dari melihat banyak anak kecil yang sering bermain di sekitar kampus Thamrin City setiap pagi hingga sore hari, membuat mahasiswi pada sa at itu berpikir a pakah mereka tidak bersekolah. Karena yang mereka lakukan hanya bermain di dala m gedung dan memainkan lift. Mereka nampak seperti mendapat permainan baru di da lam gedung.

Para mahasiswa melihat anak-anal berkeliaran papda jam sekolah merasa prihatin. Mereka mencari cara untuk membantu mereka menghabiskan waktu dengan cara-cara yang positif dan berdaya guna. Mereka mengumpulkan anak-anak ini untuk dibina dan diajarkan untuk berhitung, menulis dan membaca. Atas dasar keprihatian inilah maka kegiatan ini layak dilakukan secara terus menerus dan berkelanjutan.

\section{PENELUSURANSTUDI}

Menelisik peran mahasiswa dalam pengabdian kepada masyarakat telah banyak didokumentasikan oleh para akademisi. Berikut adalah hasil penelitian dan juga kegiatan pengabdian kepada masyarakat yang dilaksanakan oleh mahasiswa.

Karya ilmiah pengabdian kepada masyarakat (Sutisnaet al., 2017) berjudul "Membangun budaya literasi pada masyarakat di da erah kabupaten Bogor" menjelaskan tentang peran mahasiswa dalam akselerasi program pembangunan. Metode pengabdian adalah KKN tematik yang berorientasi pada bidang tertentu sesuai permasalahan kemasyarakatan dan arah kebijakan pembangunan pada wilayah tertentu. Bidang pendidikan, kesehatan, dan lingkungan menjadi fokus penga bdian kepada masyarakat tematik ini.

Pengabdian kepada masyarakat tematik lainnya (Atmojo et al, 2017). Fokus kegia tan pengabdian ini adalah pendampingan E-learning sebagai metode pembelajaran. Permasalahan yang dihadapi untuk menyelenggarakan E-learning antara lain kesiapan infrastruktur, kesiapan pengajar, dan kesiapan peserta didik. Metode pengabdian adalah pendampingan dan pelatihan E-learning pada para guru. Kegiatan yang dilakukan untuk e-learning ini a dalah pembuatan SOP, menyusun panduan e-learning bagi guru dan siswa dan a dministrator, membentuk komunitas multimedia, dan movie fest.

Peran mahasiswa dalam meningkatkan 'kesejahteraan' masyarakat sekitar kampus dilakukan oleh mahasiswa STKIP PGRI di Jombang (Qomariyah, 2019). Pemberdayaan yang dimaksud adalah dengan melakukan pendidikan, pelatihan, penyuluhan, dan pendampingan kepada masyarakat dusun tersebut selama dua bulan. Sasaran kerja para mahasiswa ini adalah Karang Taruna dan ibu-ibu PKK. Materi pelatihan dan penyuluhan adalah pemanfaatan teknologi informasi untuk memperkenalkan wilayah dusun, pelatihan pengolahan hasil lahan pertanian, pelatihan pembuatan yogurt dan ice cream sebagaibentuk olahan susu bagi ibu-ibu PKK dan remaja putri. Terdapat 7 divisi pemberdayaan; divisi ICT, divisi inovasi olahan susu, divisi pengolahan hasil tanaman, divisi karangtaruna, divisi kreativitas ibu-ibu dan remaja putri, divisi pupuk bogasi, dan divisi pendidikan. Hasil yang dica pai setelah dua bulan a dalah terwujutnya kesadaran masyarakat untuk berpartisipasi da lam meningkatkan kualitas sumberdaya manusia melalui pendidikan terutama untuk mampu mengolah susu sapi berbasis teknologi informasi (ICT) dan meningkatkan kesejahteraan masyarakat dengan cara meningkatkan pendapatan masyarakat melalui usaha mikro.

Ada pula yang menyebutkan bahwa CSR yang biasa dilakukan oleh perusahaan dapat dilakukan oleh dunia 
perguruan tinggi dengan nama Campus Social Responsibility (Rumambi et al, 2012) dan (Prasetyo, 2016). Pembangunan berkelanjutan (sustainable development) menjadi tanggungjawab seluruh masyarakat termasuk dunia pendidikan tinggi. Kampus da pat melaksanakan kegiatan atau menjadi mitra dunia usaha dalam menunaikan Corporate Social Responsibility. Hal ini sesuaidengan UUNo. 40 tahun 2007 bahwa perusahaan diwajibkan untuk melaksanakan tanggungjawab sosial dan lingkungan.

Pengabdian kepada masyarakat (Baroro \& Septarini, 2012) dilakukan dalam bentuk Campus Social Responsibility (CSR) terhadap kesejahteraan masyarakat sekitar kampus. Kegiatan ini disinergikan dalam tridharma perguruan tinggi. Salah satu kegiatan adalah pemberdayaan masyarakat melalui Usaha Mikro Kecil dan Menengah (UMKM) dalam bentuk bantuan dana, peningkatan kualitas sumber daya manusia, dan membuka akses pa da pelaku UMKM. Campus Social Responsibility menurut Baried \& Septarini (Baroro \& Septarini, 2012) merupakan perwujudan komitmen perguruan tinggi pada peningkatan kualitas kehidupan masyarakat. Metode yang digunakan adalah analisis deskriptif. Hasil penelitian menyatakan bahwa perguruan tingginegeri di Surabaya ini telah malakukan CSR da lam bentuk pengelolaan UMKM.

Tanggungjawab sosial kampus juga dipaparkan (Suba gyo \& Silalahi, 2014). Dijelaskan bahwa kampus memiliki ta nggungjawab sosial dalam bentuk tridhama perguruan tinggi terutama dharma ketiga yaitu pengabdian kepada mayarakat. Implementasi SCR ini dapat meningkatkan citra perguruan tinggi yang berdampak positif pada meningkatnya jumlah mahasiswa, rendahnya jumlah mahasiswa drop-out, rendahnya turnover dosen, meningkatnya permintaan mahasiswa kuliah praktik, dan meningkatnya daya serap lulusan. Selain itu juga nampak pada meningkatnya usa ha sektor non-formal di sekitar kampus. Sedangkan Setyawan (Setyawan, 2010) fokus pada peran empati pada mahasiswa peserta KKN. Hasil penelitian menunjukkan bahwa Kuliah Kerja Nyata membantu mahasiswa dapat melihat dirinya sendiri dan mahasiswa mampu menempatkan dirinya pada posisi orang lain.

Pengabdian kepada masyarakat oleh mahasiswa di Kabupaten Bogor (Hurriyaturrohman \& Ridwanhadi, 2017). Fokus pendampingan oleh mahasiswa ini adalah pendidikan. Pendidikan dapat mempengaruhi tinggi rendahnya ekonomi keluarga dan juga kesehatan. Metode yang dilakukan adalah bimbingan belajar pada anak-anak SD dan PAUD, pendampingan pada Posyandu, dan pelatihan pengolahan singkong menjadi nuget. Sa saran pendampingan ini a dalah anak-anak SD, anak-anak balita yang terga bung dalam Posyandu.

Pemberdayaan masyarakat yang dilakukan oleh mahasiswa dirangkum oleh Anwas (Anwas, 2011) melalui kuliah kerja nyata tematik Pos Pemberdayaan Masyarakat (Posdaya). Fokus pendampingan adalah pendidikan, kesehatan, kewirausahaan, dan lingkungan.
Posdaya adalah salah satu model pemberdayaan masyarakat dengan mengutamakan peran atau partisipasi masyarakat dalam memecahkan permasalahan yang dihadapi oleh mesyarakat itu sendiri.

Menurut Sumardjo dalam (Anwas, 2011) disebutkan bahwa kunci pemberdayaan masyarakat adalah melibatkan masyarakat seluas-luasnya, berpusat ppada kebutuhan masyarakat, dan menggunakan pendekatan holistik. Kegiatan pengabdian kepada masyarakat oleh mahasiswa juga dilakukan oleh mahasiswa jurusan Sekretaris ASM BSI Bandung (Fauzzia et al, 2018). Mahasiswa ini bekerjasama dengan pengurus DKM Masjid Fatimah Hidayah Bandung. Metode pelaksanaan adalah bakti sosial berupa gotong royong untuk mera wat masjid dan tebar mukena yang dilakukan oleh ena m mahasiswa dan sa tu orang dosen.

Fathurrohman (2017) menjelaskan pen gabdian kepada masyarakat yang dilakukan oleh mahasiswa Universitas Yudharta Surabaya. Para mahasiswa merintis sebuah sekolah untuk anak-anak. Hasil kajian diketahui bahwa persoalan pokok di masyarakat dimana pengabdian kepada masyarakat dilakukan adalah permasalahan pendidikan yang sangat rendah. Hal ini disebabkan oleh loka si dusun dan SDM yang didominasi lulusan SD dan SMP. Untuk menjawab permasalahan masyarakat ini maka dijawab dengan kegiatan rintisan pendidikan anak usia dini dengan metode pendampingan bagi anak-anak usia dini. Kegiatan ini dimulai dengan koordinasi dengan perangkat desa setempat untuk mendata anakanak dalam kategori usia 4-6 tahun. Kemudian dilanjutkan dengan peresmian rintisan TK sedangkan tim pengajar adalah warga setempat. Untuk itu, mahasiswa mendampingi para calon guru supaya para calon guru ini mampu menjadi guru walaupun pendidikan mereka masih sangat minim.

\section{METODE}

Gelar Tikar mengambil tema "enjoyable learning" untuk membentuk program kegiatan ini. Mahasiswi membuat program kegiatan ini dengan nama Gelar Tikar. Dilihat dari nama kegiatannya, kegiatan ini merupakan kegiatan yang dilakukan di atas tikar yang digelar, da n terdapat proses belajar mengajar di atasnya.

Kegiatan ini merupakan salah satu wadah para mahasiswa untuk bersosialisasi dengan a nak-anak kecil tersebut dengan menjadi pembimbing yang memberikan materi kepada anak-anak. Melalui kegiatan ini mahasiswa diharapkan agar dapat bekerja sama secara suka rela untuk mengajari mereka dengan sebuah materi dala m bahasa Indonesia maupun bahasa Inggris.

Pengajaran yang diberikan bersifat enjoyable learning sehingga anak-anak merasa nyaman dan mampu menyerap materi yang diajarkan. Yang dimaksud enjoyable learning disini, para peserta dan pendamping duduk melingkat satu sama la in da pat bertatap muka. Disetiap materi, mahasiswa menyisipkan gambar- 
gambar sehingga pesan dapat mudah dipahami oleh anak-anak dan mereka selalu dibiasakan untuk berbicara bahasa inggris, seperti perkenalan diri dan bercenta mengenai harinya.

Dengan mengikuti Gelar Tikar, para mahasiswi memiliki kesempatan untukberbagi ilmu dankeceriaan dengan anak-anak di Panti Asuhan Fajar Baru kota Depok. Para mahasiswa memberikan pelajaran Bahasa Inggris kepada anak-anak yatim piatu tersebut dengan beberapa macam media, seperti kuis, tanya jawab, pembahasan materi sekolah, dan permainan. Dengan begitu, keahlian dan tingkat pemahaman setiap anak bisa diketahui oleh mahasiswi Gelar Tikar dan mereka bisa menyesuaikan materi yang disampaikan kepada setiap anak. Para mahasiswi juga belajar untuk menghibur anak-anak tersebut. Seringkali, ketika mahasiswa datang ke panti a suhan, a nak-anak tersebut senang karena mendapatkan teman baru.

Sa at ini, Gelar Tikar mengajar di Panti Asuhan Fajar Baru, Kota Depok. Para mahasiswi dibagi menjadi beberapa kelompok mengajar (tergantung dari mahasiswi yang mendaftar setiap tahunnya) dan kelompok mengajar tersebut secara bergiliman mendapat tugas untuk mengajar setiap hari Senin. Sebelum kelompok Gelar Tikar mengajar, wakil Ketua Gelar Tikar memberi materi tentang teknik pengajaran dan kelompok Gelar Tikar pun belajar bersama mengenai materi tersebut. Salah satu kegia tan mengajar ini adalah mengajar Bahasa Inggris untuk anak SD hingga SMP. Materi pengajaran disarikan dari berbagai sumber dan disesuaikan dengan tingkat pemahaman para peserta.

Materi yang diajarkan adalah Bahasa Inggris dasar, misalnya tentang perkenalan diri, mendeskripsikan situasi, penambahan vocabulary, struktur ka limat dan tenses seperti simple past, simple present dan simple continuous. Sebelum tahun pengajaran 2018-2019, Gelar Tikar memberikan materi yang sudah disiapkan da lam lembaran kertas. Namun penggunaan lembaran kertas dianggap tidak efisien karena lembaran kertas tersebut dapat hilang atau tercecer. Ide selanjutnya adalah dengan menggantikan materi dalam lebaran kerta s dengan beberapa pack buku tulis yang dibagikan kepada setiap anak; satu a nak diberikan sa tu buku tulis.

Sa at ini kegiatan UKM Gelar Tikar mengajarkan Bahasa Inggris kepada anak-anak sesuai tingkatan kelas mereka, dan membantu mereka mengerjakan PR sekaligus membantu mereka belajar untuk persiapan ujian. Untuk menyemangati mereka dalam belajar, dalam satu semester kemarin kami membuat sebuah lomba kecil, dimana mereka yang bisa dengan percaya diri berbica ra dengan Bahasa Inggris akan mendapatkan hadiah berupa makanan kecil seperti beng-beng dan coki-coki. Dan untuk menutup semester kemarin, kami para anggota Gelar Tikar mengadakan lomba kecil lagi, namun dengan kelompok. Lomba dibagi kedalam 3 kelompok, yang satu kelompok terdiri dari 4 hingga 5 orang. Lomba ini seperti cerdas cermat, dimana kami memberi pertanyaan, lalu sia pa yang cepat yang dapat menjawab. Pertanyaan yang diberikan seputar Grammar, seperti vocabulary, tenses, dan struktur kalimat. Dengan kegiatan ini, diharapkan apa yang sebelumnya para anggota UKM Gelar Tikar dapat dipahami anak-anak panti asuhan dan mereka dapat mengerti mengenai Bahasa Inggris karena pentingnya Bahasa Inggris sa at ini.

\section{PELAKSANAAN}

UKM Gelar Tikar ini merupakan UKM yang ada diba wah naungan UKM Pendidikan. Saat ini jumlah dari anggota UKM Gelar Tikar sebanyak 28 orang, yang bera sal dari semester 2,4 dan 6 Program Studi Ilmu Komunikasi. Setiap 2 bulan, mahasiswa mengadakan evaluasi mengajar. Mahasiswa dapat saling sharing penga laman mengajar, berbagi informasi mengenai halhal yang harus ditingkatkan la gi, dan ba gaimana cara menangani a nak - anak yang "sulit diatur". Tidakjarang mahasiswa mengeluh karena mereka harus pulang lebih malam, namun demi ingin membagikan ilmu kepada anak - anak panti serta melatih dan demi keinginan untuk berlatih berkomunikasi yang baik dengan anak anak, dan juga mengembangkan Bahasa Inggris mahasiswa itu sendiri, mereka dengan senang hati melakukan kegiatan tersebut.

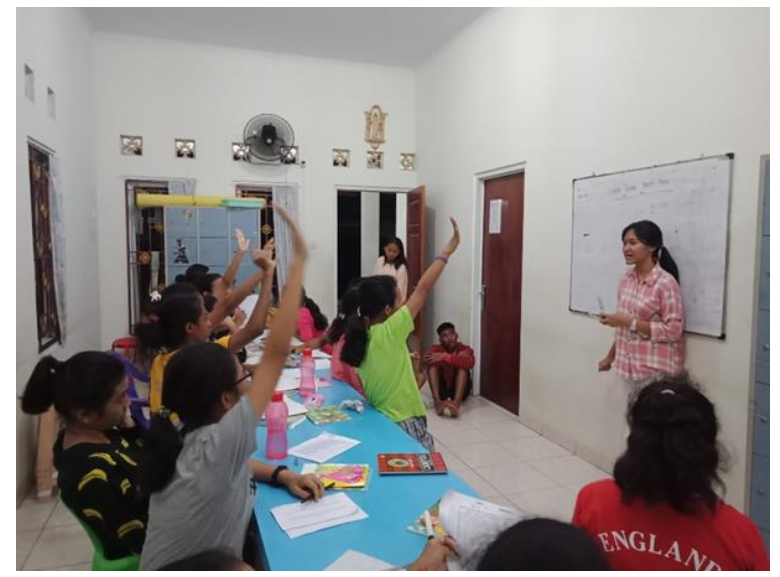

Gambar 2. Mahasiswa sedang mangajar.

Untuk menyiapkan alat peraga mengajar dan kepertuan lain yang mungkin timbul da ri kegiatan ini, mahasiswa seca ra suka rela mendonasikan uang jajan mereka untuk iuran yang hasilnya digunakan untuk kegiatan mengajar oleh tim Gelar Tikar. Setiap mahasiswa wajib membayar Rp. 5000 per minggunya, dan uang kas tersebut digunakan jika mereka membutuhkan materi yang harus di foto copy dan kebutuhan pengajaran lainnya.

Pada awal Gelar Tikar ini dimulai, para mahasiswi mengajar anak - a nak di sekitar Tanah Abang. Sebelum tahun ajaran 2018-2019, Gelar Tikar sela ma 2 tahun berkegia tan mengajar di Panti Griya Asih, Jakarta Pusat. Namun karena kepadatan jadwal kunjungan tamu ke Panti Griya Asih, kamimemutuskan mencari Panti lain untuk menjadi tempatbagikami mengajar. 
Anggota Gelar Tikar memutuskan Panti Asuhan Fajar Baru Depok Jawa Barat yang akan menjadi tempat mengajar selanjutnya, namun lokasinya mudah dijangkau dengan menggunakan kereta. Kami berangkat bersa ma-sama dari Thamrin City kePanti Asuhan Fajar Baru dengan kereta. Perjalanan yang kami tempuh sekitar 1 (satu) jam hingga 1,5 (satu setengah) jam. Kami turun di Stasiun Depok, dan melanjutkan perja lanan dengan taksionline atau ojek online.

Dalam kegiatan mengajar, kami hanya menggunakan fasilitas papan tulis dan spidol yang telah tersedia di Panti Asuhan Fajar Baru, la lu anak-anak menulis materi pada buku yang telah kami berikan, namun terkadang mahasiswa harus menggunakan handphone sebagai a at bantu mengajar. Handphone digunakan pada saat kuis. Mahasiswa mengunggah materi kuis ke dalam sebuah aplikasi yang dapat digunakan untuk upload mater berupa pertanyaan-pertanyaan multiple choice. Cara ini membuat suasana Gelar Tikar lebih berwarna, anakanak pun senang ka rena tidak sela lu hanya mencatat di buku.

Kegiatan mahasiswa ini dilaksanakan setiap hari Senin pukul 17.00-18.00. Namun faktanya mereka mengajar lebih dari waktu yang ditentukan. Antusiasme anak anak pantiy ang begitu luar bia sa memotivasi mahasiwa untuk menambah waktu pendampingan kepada anakanak panti tersebut. Jumlah anak - anak panti yang biasanya mengikuti kegiatan Gelar Tikar ini dari 12 hingga 21 anak. Anak-anak tersebut dibagi menajdi dua kelompok yaitu kelompok murid SD dan kelompok siswa SMP, umur 6-14 tahun. Mereka terdiri dari 15 Perempuan dan 10 laki-laki.

Dengan mengikuti Gelar Tikar, para mahasiswi memiliki kesempatan untuk berbagi ilmu dankeceriaan denga n anak-anak dipanti a suhan. Mereka membenkan pela jaran Bahasa Inggris kepada anak-anak y atim piatu tersebut dengan beberapa macam media, seperti kuis, tanya jawab, pembahasan materi sekolah, dan permainan. Dengan begitu, keahlian dan tingkat pemahaman setiap anak bisa diketahui oleh mahasiswi Gelar Tikar dan mereka bisa menyesuaikan materi yang disampaikan kepada setiap a nak. Para mahasiswi juga bela jar untuk menghibur anak-anak tersebut. Seringkali, ketika datang ke panti asuhan, anak-anak tersebut senang karena mendapatkan teman baru a tau seorang sosok "kakak".

Jika anak-anak di panti asuhan mendapatkan ilmu pengetahuan bahasa inggris dan hiburan dari kakakkakak mahasiswa anggota Gelar Tikar, para mahasiswa mendapatkan pengalaman yang sama berharganya dari anak-anak tersebut. Setiap kali kami datang untuk mengajar, kami selalu mendapatkan pengalaman yang menyenangkan, yaitu mengajarkan anak-anak tersebut dan bercanda dengan mereka. Karena sebagian besar anak di panti asuhan memiliki kepribadian yang ceria dan rasa penasaran yang tinggi, mereka sering ingin bercanda dan bertanya dengan kami. Selain itu, semangat belajar mereka juga menjadi inspirasi kami untuk lebih gia t belajar di kampus. Tidak sedikit anak di panti asuhan yang masih ingin membahas atau menjelaskan lebih lanjut sebagian materi, walaupun waktu mengajar sudah usai. Hal ini karena mereka sangat menikmati waktu belajar mereka dengan kami, dan mereka memiliki ra sa bangga tersen diri ketika kami memuji mereka saat mereka berhasil mela kukan tugas atau kuis dengan baik.

Melalui kegiatan Gelar Tikar, para mahasiswa mendapatkan banyak inspirasi dan pelajaran dari kegia tan ini dan dari waktu y ang kami habiskan dengan anak-anak di panti asuhan. Ka mi sadar bahwa mereka yang kurang beruntung untuk melanjutkan edukasi formal saja masih sangat semangat untuk belajar, sedangkan sulit bagi kami yang memiliki kesempatan berkuliah untuk lebih giat belajar. Antusiasme yang ditunjukkan anak-anak tersebut juga memberikan motivasi yang kuat bagi kami untuk lebih semangat da la $m$ mengajari mereka, karena melihat keinginan dan ketekunan mereka dalam mengikuti pelajaran dengan kami. Selain itu, kami juga sadar bahwa dari banyak segi, ka mi lebih berkecukupan dari anak-anak tersebut, tetapi kepribadian dan seman gat mereka membuat kami sadar bahwa kami mungkin kurang memiliki rasa syukur dengan semua "keunggulan" yang kami dapatkan tetapi mereka tidak.

\section{PEMBahasan}

Kegiatan Gelar Tikar ini tidak hanya menguntungkan anak-anak di panti a suhan, namun para mahasiswa juga mendapat pengalaman belajar yang sesungguhnya. Setiap mahasiswa datang untuk mengajar, mereka mendapatkan pengalaman yang berbeda; pengalaman yang menyenangkan, yaitu mengajarkan anak-anak tersebut dan bercanda dengan mereka. Anak-anak sangat antuasia mengikuti kegiatan ini, da n antusiasme a nak-anak inila h yang emnjadi motivasi para mahasiswa untuk tetap meluangkan wa ktu, tenaga dan sumber dana untuk tetap menjadi pendamping mereka. Berbagai macam kepribadian dan latarbelakang yang dimiliki oleh anak-anak di panti a suhan menjadikan hal tersebut sebagai salah satu tantangan untuk dapat memahami karakter mereka. Keunikan para peserta sungguh mendorong para mahasiswa untuk berlath bersabar, melatih mahasiswa untuk mampu mengendalikan emosi dan mengendalikan sikap mereka untuk dapat menjadi sosok yang dapat dicontoh oleh mereka. Hal lain yang mereka dapatkan adalah berla tih mengungkapkan ide dan ga ga san yang dapat dengan mudah diterima oleh anak-anak yang sangat unik tersebut. Dengan bahasa dan ga ya komunikasi yang sederhana, anak-anak dapat menyerap materi den gan baik tanpa haru s dipaksa.

Antusia sme yang ditunjukkan anak-anak tersebut juga memberikan motivasi yang kuat kepada mahasiswa untuk lebih bersemangat dalam mengajari mereka. Mereka terlihat tekun dalam mengikuti pelajaran. Selain itu, para mahasiswa juga menyadari ba hwa dari banyak segi, mereka lebih beruntung karena mereka lebih berkecukupan dari anak-anak tersebut, tetapi 
kepribadian dan semangat mereka membuat para mahasiswa sadar bahwa mereka mungkin kurang memiliki ra sa syukur dengan semua "keunggulan" yang mereka miliki.

Sela in kegia tan belajar dan bermain bersama, anak-anak di panti asuhan memanfaatkan waktu untuk melontarkan pertanyaan yang membuat mahasiswa saling bertukar cerita tentang kehidupan. Tukar penga laman mengenai kehidupan ini membuat mereka senang untuk selalu bersama para mahasiswa walaupun ja m belajar telah u sai. Para mahasiswa dapat merasakan bahwa mereka tidak merasakan keberuntungan yang sama seperti anak-anak diluar sa na yang mendapatkan kasih sayang secara khusus dari kedua orang tua kandungnya. Oleh karena itu mahaisswa selalu membuat mereka semangat dan tetep mendukung segala kegia tan yang mereka ikuti karena hal itu yang membuat mereka memiliki kesenangan tersendiri dengan ha dirnya mahaisiswa yang mungkin dianggap sebagai anggota keluarga yang baru bagi mereka.

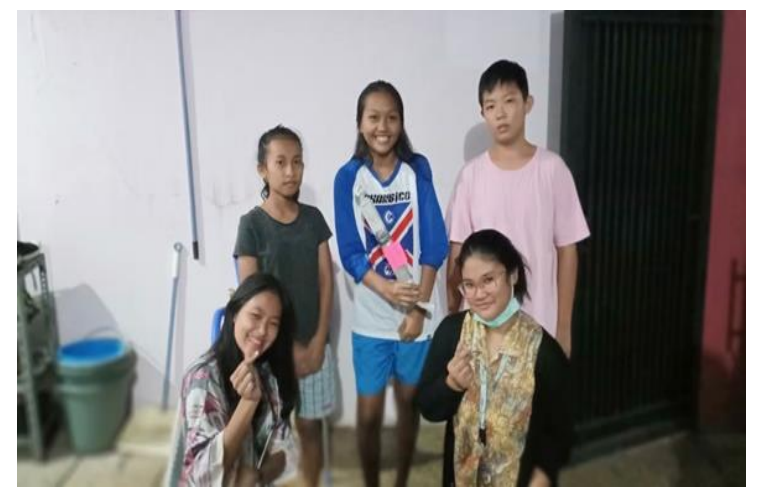

Gambar 3. Pengabdi bersama nak-anak didiknya.

Para mahasiswa merasa beruntung ka rena mempunyai kesempatan untuk bisa mengajar anak-anak di Panti Asuhan Fajar Baru. Selain menjadipengajar, mahasiswa bisa menambah kegiatan positif diluar kampus dan memperluas relasi. Mereka menjadi sa dar bahwa masih banyak anak-anak di Indonesia yang masih kurang mendapatkan pengetahuan yang seharusnya mereka dapatkan. Untuk mendapatkan pengetahuan secara akademik di zaman sekarang terbilang mudah untuk dida patkan, tetapi untuk pelajaran moral dan karakter karena mereka kurang mendapat perhatian khusus dari orang tua kandung. Oleh karena itu mahasiswa hadir untuk menemani mereka, membantu mereka untuk menjadi pribadi yang lebih baik, karena mereka merupakan salah satu asset negara yang akan melanjutkan generasi bangsa ini.

\section{KESIMPULAN}

Tujuan kegiatan ini a dalah untuk memberdayakan anakanak Panti Asuhan. Kegiatan ini mendapat respon sangat positif. Dengan adanya kegiatan dari para mahasiswa, anak-anak dapat memanfaatkan waktu mereka secara efektif dan efisien dengan kegiatan yang bermanfaat bagi masa depan mereka. Di sisi yang lain, dampak dari kegiatan ini juga dirasakan oleh para penga bdi yaitu meningkatnyara sa berbela rasa dan juga empati yang tinggi kepada sesama. Oleh karena itu, kegiatan ini layak dilanjutkan dan melibatkan lebih banyak civitas akademik sehingga akan lebih banyak anak panti asuhan yang mendapatkan sentuhan kasih dari para pengabdi. Kegiatan ini juga bermanfaat bagi kampus dalam memberikan sumban gan berupa keahlian dan keterampilan untuk memberdayakan masyarakat sekita kampus. Dengan demikian, kampus tidak hanya mengajarkan teori tentang kehidupan tetapi memberi ruang bagi mahasiswa untuk belajar secara nyata di masyarakat dengan memberikan pendampingan kepada anak panti asuhan secara terus menerus dan berkelanjutan.

\section{DAFTAR PUSTAKA}

Anwas, O. M.(2011). Kuliah Kerja Nyata TematikPos Pemberdayaan Keluarga Sebagai Model Pengabdian Masyarakat Di Perguruan Tinggi. Jurnal Pendidikan Dan Kebudayaan, Vol. 17 No. 5, hal. 565

Atmojo, Eko Murdyantoro, Acep Taryana, M. I. Z. (2017). KKN Tematik Pendampingan Implementasi E-learning di SMK YPT 2 Purbalingga. Posiding Seminar Nasional dan Call for papers.

Baroro, A., \& Septarini, N. (2012). Analisis Pengaruh Kebijakan Campus Social Responsibility Terhadap Kesejahteraan Masyarakat Sekitar ( Studi Kasus Tiga Perguruan Tinggi Negeri Di Surabaya), Prosiding Seminar \& Konferensi Managemen Bisnis, hal. 142-149.

Fathurrohman, A. (2017). Rintisan Pendidikan Anak Usia Dini Suku Tengger di Wilayah Terpencil Dusun Surorowo, Desa kayukebek, Kec. Tutur Kabupaten Pa suruan. Prosiding Ancoms 2017, (110), 408-416.

Fauzzia, W., Sofiani, F., Sha leha, D. N., \& Malik, N. A. (2018). Pengabdian Kepada Masyarakat Bakti Sosial Bersama Jamaah Masjid Fatmah Hidayah. Jurnal Pengabdian kepada Masyarakat, Vol. 1, No. 1, hal. 81-86.

Hurriyaturrohman, Ridwanhadi, M. F. (2017). Pemberdayaan Masyarakat tentang Pendidikan, Ksehatan, dan Ekonomi dalam rangka Mewujudkan Masyarakat yang Berkualitas di Desa Cibeteung Muara. Jurnal Pengabdian Kepada Masyarakat,01,No.01,46-53.

Prasetyo, A. G. (2016). Campus Social Responsibility dan Basekolah: Innovasi Penanganan Anak Putus Sekolah. In Buku Seri Innovasi \& Administrasi Negara Vol2.

Qomariyah, U. N. (2018). Pemberdayaan Masyarakat dusun Anjasmara desa Jarak Wonosalam Sebagai Upaya Meningkatkan Mutu Sumber Daya Manusia ( SDM . Jurnal ELPEDUAEM. Vol. 4 No. 3 Edisi Oktober, hal. 19-26.

Rumambi, Hedy D \& Lintong, J. S. (2017).Implementasi Tanggungjawab Sosial 
Institusi Pendidikan Tinggi. JurnalEkonomi Dan Keuangan, Vol. 1 No. 2 Edisi Juni 20178 hala. $145-163$.

Setyawan, I. (2010). Peran Kemampuan Empati pada Efikasi Diri Mahasiswa Peserta Kuliah Kerja Nyata PPM Posdaya. Prosiding Konferensi Na sional II Ikatan Psikologi Klinis Himpsi (pp. 296-300).

Subagyo \& Silalahi, A. P. B. (2014). Implementasi Tanggungjawab Sosial Pperguruan Tinggi dan Dampaknya terhadap Citra Kampus di Universitas Nusantara PGRI Kediri. Jurnal Nusantara of Research Universitas Nusantara PGRI Kediri, 01 No 02, 191-205.

Sumardjo. (2008). Penyuluhan Pembangunan Pilar Pendukung Kemajuan dan Kemandirian Masyarakat. In Memberdayakan Manusia Pembangunan yang Bermartabat. Bogor: PustakaBangsaPers.

Sutisna, S. P., Fahri, M. F., Khofifah, W., Teknik, D. F., Teknik, M. F., \& Mulya, D. G. (2017). Membangun budayaliterasi pada masyarakat di daerah Kabupaten Bogor. Jurnal Pengabdian kepada Ma syarakat Universitas Negeri Medan, Vol. 1 No. 1 Edisi Desember hal.90-96. 